\title{
Englishes in the Expanding Circle: Focus on Asia
}

\author{
Andy KIRKPATRICK \\ Griffith University \\ Brisbane, Australia
}

\begin{abstract}
In Kachru's original classification, the countries of the Expanding Circle were those where English was learned primarily as a foreign language in schools. English did not play an institutional role within the country. As such they were "norm-dependent" countries relying on exonormative native speaker standards as models and targets for learners of English. In recent years, however, the role(s) of English in many Expanding Circle countries of Asia - these include the economic powerhouses of China, Japan and South Korea - have increased exponentially both within the countries (as English becomes increasingly important as a language of education, for example) and between the countries as a lingua franca (English has been enshrined as the sole working language of the Association of Southeast Asian Nations (ASEAN), for example). The aim of this article is to describe how these roles of English in the Expanding Circle countries of Asia have developed. I shall focus on the role of English as a language of education in describing how the role of English has developed within countries and on the role of English as a lingua franca in describing how the role of English has developed between the Expanding Circle countries of Asia. I shall conclude by considering the implications of these developments for English language education pedagogy and policy.
\end{abstract}

Keywords: Expanding Circle, Outer Circle, English as a lingua franca, varieties of English, East and Southeast Asia

\section{For citation:}

Kirkpatrick, Andy. 2020. Englishes in the Expanding Circle: Focus on Asia. Russian Journal of Linguistics 24 (3). 551-568. DOI: 10.22363/2687-0088-2020-24-3-551-568

Научная статья

\section{Варианты английского языка Расширяющегося круга: в фокусе - Азия Энди КИРКПАТРИК}

Университет Гриффита Брисбен, Австралия

\begin{abstract}
Аннотация
В оригинальной классификации Б. Качру Расширяющийся круг включает такие страны, где английский преимущественно изучается в школе как иностранный язык. В самих этих странах английский язык не играет институциональной роли. Посему эти страны называются «нормозависимыми», полагающимися на экзонормативные стандарты носителей языка как модель и цель при изучении английского языка. Однако в последние годы роль английского языка во многих азиатских странах Расширяющегося круга - а такие страны включают
\end{abstract}


государства с мощной экономикой, такие как Китай, Япония и Южная Корея - значительно усилилась как внутри этих стран (поскольку английский приобретает все большую значимость, например, в сфере образования), так и между этими странами в качестве языкапосредника, или лингва франка (английский язык является, например, единственным рабочим языком Ассоциации государств Юго-Восточной Азии - ACEAН). Цель данной статьи раскрыть, как усиливалась роль английского языка в азиатских странах Расширяющегося круга. Фокус сделан на значении английского как языка образования при описании процесса расширения его роли в этих странах, а также на роли английского как лингва франка между азиатскими странами Расширяющегося круга. В заключение делаются выводы о значимости этой роли английского языка для методики преподавания и образовательной политики.

Ключевые слова: Расширяюшийся круг, Внешний круг, английский как язык-посредник (лингва франка), варианты английского языка, Восточная и Юго-Восточная Азия

\section{Для цитирования:}

Kirkpatrick A. Englishes in the Expanding Circle: Focus on Asia. Russian Journal of Linguistics. 2020. Vol. 24. № 3. P. 551-568. DOI: 10.22363/2687-0088-2020-24-3-551-568

\section{Introduction}

In this article, I shall look at the current roles of English both within and between the Expanding Circle countries of Asia. First I need to explain what Asia will constitute in the terms of this article. Asia represents an enormous area and the most linguistically diverse continent on earth with $34 \%$ or 2301 of the world's 7102 living languages (Lewis, Simons \& Fennig 2015). It would be impossible to cover all this diversity in a single article and my main focus will be on the countries of East and Southeast Asia, although I shall also refer to South Asia, in particular Nepal, in the discussion on the role English is playing in education.

The article will first consider the new roles English is playing within the nations of the Expanding Circle and then consider its new roles between the nations of East and Southeast Asia, especially its role as a lingua franca. In the first part of the article, I shall look at how the roles of English within the Expanding Circle countries of East and Southeast Asia have developed, especially as a language of education from primary to higher education. In Kachru's original formulation (1992), the place of English in Expanding Circle countries was restricted to its place as a school subject where it was taught as a foreign language. These Expanding Circle countries were norm dependent, meaning they relied on native speaker varieties of English as classroom models and targets for learners to strive for. English was also "foreign" in the sense that it played no role within the countries. This was a major difference between Expanding Circle and Outer Circle countries. In Outer Circle countries, English, as a result of these countries having been colonies of English-speaking empires, played an institutional role and local varieties of English, such as Filipino English and Singaporean English, developed.

In the second part of the article, I shall describe how English is playing an increasingly wide and important role as a lingua franca between the nations of Asia. Here, it will be necessary to include Outer Circle countries in the discussion as English is being used as a lingua franca by Asian multilinguals from both Expanding and Outer Circle countries. As will be illustrated below, its official role as the sole working language of the Association of Southeast Asian Nations 
(ASEAN) exemplifies its role as a lingua franca between Outer and Expanding Circle countries. Of the ten nations that form ASEAN, four that were colonies of either Britain or the United States (Brunei, Malaysia, The Philippines, and Singapore) can be classified as Outer Circle countries and are home to local varieties of English. Five (Cambodia, Indonesia, Laos, Thailand, and Vietnam) can be classified as Expanding Circle countries. With the exception of Thailand, all were some form of colony but not of English-speaking empires. The tenth nation of ASEAN, Myanmar, is difficult to classify. While it was a colony of Britain, it went into a form of self-isolation in 1962 for decades, during which time Burmese was the sole medium of education, and English stopped playing any institutional role and became a foreign language. I shall describe the role of English as a lingua franca between the countries of Asia and exemplify this with examples taken from the Asian Corpus of English (ACE), a corpus of the naturally occurring use of English as a lingua franca across Asia.

In the third part of the article I shall consider the implications of these increasing roles of English both within and between the countries of Asia for English language teaching and language education policy.

\section{The role of English within the Expanding Circle countries}

English is playing an increasing role in both Outer and Expanding Circle countries of Asia. As Bolton and Bacon-Shone note:

Since the era of European decolonisation in Asia, which largely took place from the late 1940s to the 1960s, there has been a massive expansion in the spread of English throughout the whole of the region, in both Outer Circle and Expanding Circle societies (Bolton \& Bacon-Shone 2020: 49).

Using data from language surveys and government censuses, Bolton and Bacon-Shone have estimated the number of English users in the Expanding Circle countries of Asia. The numbers and percentages are shown in Table 1.

Table 1

Knowledge of English in Expanding Circle Asian societies

\begin{tabular}{|l|c|c|c|}
\hline Society & Bolton (2008) & Current estimates & Approx. total of English speakers \\
\hline Nepal & $30 \%$ & $30 \%$ & 8.5 million \\
\hline Macau† & - & $28 \%$ & 0.2 million \\
\hline China & $25 \%$ & $20 \%$ & 276.0 million \\
\hline Myanmar (Burma) & $5 \%$ & $10 \%$ & 5.2 million \\
\hline Japan & $20 \%$ & $10 \%$ & 12.5 million \\
\hline South Korea & $10 \%$ & $10 \%$ & 5.1 million \\
\hline Taiwan & $10 \%$ & $10 \%$ & 2.4 million \\
\hline Thailand & $10 \%$ & $10 \%$ & 6.5 million \\
\hline Vietnam & $5 \%$ & $10 \%$ & 4.6 million \\
\hline Cambodia† & $5 \%$ & $5 \%$ & 0.8 million \\
\hline Indonesia & $5 \%$ & $5 \%$ & 13.0 million \\
\hline Laos & $5 \%$ & $5 \%$ & 0.3 million \\
\hline Total & & & $\mathbf{3 3 5 . 1}$ million \\
\hline
\end{tabular}


This suggests that the total number of users of English in the Expanding Circle countries of Asia is nearly equal to the total number of native speakers of English. Clearly the most striking figures concern China, and I will therefore consider the Chinese case in more detail here. The question to ask is why so many Chinese are learning English.

One answer is that they have to. English is now a compulsory subject for all school children from Grade 3 of primary school. The importance attached to English is evidenced by the fact that English is one of three core subjects that students have to take in the highly competitive gao kao, the national schoolleaving/university entrance exam. The other two core subjects are Mathematics and Chinese itself. That those parents who can afford it send their children to Englishmedium kindergartens shows that there is strong demand for English among the Chinese. This demand is in turn reflected in the increasing popularity of kindergartens where English is used as the medium of instruction (Feng \& Adamson 2019).

This also illustrates the desire of Chinese to connect with the world as they see English as a primary vehicle for doing this, As Bolton, Botha, and Zhang point out (2020: 523), English connects Chinese people to the world "either directly, through travel or education abroad, or even symbolically, by connecting young people to life outside mainland China, at a range of levels, from popular culture to current affairs or to various forms of academic knowledge." English has thus become much more than just a foreign language in China. In addition to offering a connection to the world, English in China is also playing a political role, especially in on-line media. Many Chinese netizens are creatively adapting English to poke fun at or express opposition to the Chinese Communist Party's official line. To do this they have changed the spelling of certain English words to produce neologisms to indicate new meanings. Examples include "harmany," "departyment," "goveruption," "freedamn," and "democrazy" (Li 2014 n.p.). On-line media are also home to a "mixed code variety of Chinese English" (Zhang 2012: 40). Some sites even make the mixing of the two languages obligatory (Zhang 2012).

The English spoken by Chinese users is also beginning to develop Chinese characteristics (Kirkpatrick 2015). This example from Xu (2010) shows how the Chinese preference for prefacing cause before effect in a "because-therefore" sequence (Kirkpatrick 1995) is reflected in the way speakers order cause and effect in English:

A: When you first got to the Great Wall, how did you feel?

B: Some stranger feelings, because I couldn't get the same feeling as others, because others always feel powerful, and happy or others, because I didn't have some special feeling, so I feel sad.

If $B$ were a speaker of a native variety of English s/he would probably have started the answer by saying something like:

B: I felt sad because.... 
The place English currently occupies in the school curricula means that it has become the second language of education in China after Putonghua itself, the national lingua franca. More Chinese are learning English than they are the other languages of China, including Cantonese (Yue), Shanghainese (Wu), Hakka (Kejia $\mathrm{Hua}$ ), and Hokien (Min Nan Hua). In fact, the Language Law of China expressly forbids the use of Chinese languages other than Putonghua as languages of education (Kirkpatrick \& Xu 2001, see also http://www.gov.cn/english/laws/200509/19/content64906.htm). All Chinese schoolchildren learn two languages: the national language, Putonghua, and English.

English is also the second language of education at the tertiary level. Nearly 20 years ago, Zhu Rongji, then the Chinese Premier, addressed his alma mater, the School of Economics and Management at the highly prestigious Tsinghua University in Beijing, saying. "'I hope all classes will be taught in English. I don't worship foreign languages. But we need to exchange our ideas with the rest of the world" (Kirkpatrick 2011: 110). Today over 1000 of China's 1448 tertiary institutions have established English medium programmes. This is part of China's plan to attract international students, and the aim is to have an extraordinary 35.5 million international students studying in China by the end of 2020. This will require establishing even more English-medium of instruction (EMI) courses (Galloway, Numajiri \& Rees 2020). (This target, of course, has been missed because of the Covid crisis.)

China is the Expanding Circle country with the highest population and the largest number of English users. I will compare this with the situation in one of Asia's smallest Expanding Circle countries in terms of population, Nepal. Table 1 shows that while there are fewer than one million English users in Nepal, they represent $30 \%$ of the population. While relatively sparsely populated, Nepal is home to some 125 indigenous languages, about 30 of which have fewer than 100 speakers (Sunuwar 2020). Recent moves to more democratic governments since the overthrow of the Shah kings in 2006 have seen policies promoting mothertongue based multilingual education, but these have not been implemented successfully. Instead, the Ministry of Education has legitimised English as a medium of instruction for private schools and allowed that the national language, Nepali, and English both be mediums of instruction in public schools. The Ministry also mentions that mother tongues can be used as the medium of instruction in primary schools (Phyak \& Ojha 2019). However, parental demand and the belief, mirrored throughout the Expanding Circle countries of Asia, that English opens the door to international communication and participation in globalisation (Kirkpatrick \& Liddicoat 2019) has actually resulted in most state schools following private schools in making English the medium of instruction. Secondary schools fear they will lose pupils to the private sector if they offer only Nepali-medium education. This does not mean, of course, that English is necessarily being learned. As the authors of a recent Nepalese study "Medium of Instruction and Languages for Education" reported: 
The lack of books and materials, or even of teachers who speak English, does not seem to have cautioned schools away from embarking on the change. In reality, most "English medium" schools would seem to be using Nepali quite extensively alongside English, but without the benefits of a planned approach to bilingual teaching. Training and resourcing for English falls vastly short of what is required, even to achieve effective teaching of English as a subject (Seel et al., 2015: xii, cited in Phyak \& Ojha 2019)

This tension between a desire to enhance mother-tongue based multilingual education to preserve the linguistic diversity of the country and the neoliberal agenda which promotes English as the language of education which will offer pathway to participation in globalisation is reflected in many other countries.

To turn now to the countries that make up the Association of Southeast Asian Nations (ASEAN), Table 2 below shows when English is first introduced into the school curriculum in each of the ten countries.

Table 2

The National Language and English in Education in ASEAN

\begin{tabular}{|l|l|l|}
\hline \multicolumn{1}{|c|}{ Country } & \multicolumn{1}{|c|}{ Medium of Instruction } & \multicolumn{1}{c|}{ First Foreign Language (Year of Introduction) } \\
\hline Brunei* & Malay and English & English (primary 1 as Mol) \\
\hline Burma & Burmese & English (primary 1) \\
\hline Cambodia** & Khmer & English (primary 5) (French also offered) \\
\hline Indonesia** & Bahasa Indonesia & English (secondary 1) \\
\hline Laos & Lao & English (primary 3) \\
\hline Malaysia & Malay and Vernaculars & English (from primary 1) \\
\hline Philippines & Local languages (until P3) & English (from primary 1 as Mol) \\
\hline Singapore & English & Malay/Mandarin/Tamil (primary 1) \\
\hline Thailand & Thai & English (primary 1) \\
\hline Vietnam** & Vietnamese & English (primary 3 in selected schools) \\
\hline
\end{tabular}

* The Arabic script, jawi, is introduced from primary 3

** Some bilingual education for minority groups in early primary

(Table adapted from Kirkpatrick \& Liddicoat 2017)

Table 2 shows that English has become the second language of education (after the respective national languages) in nine of the ten countries. In the tenth, Singapore, English is the first language of education. The promotion of English as a language of education is replicated across Asia. In a recent Handbook on Language Education Policy in Asia (Kirkpatrick \& Liddicoat 2019) the following trends were identified:

(i) the promotion of the respective national language as a symbol of national identity and unity;

(ii) the promotion of English as the second language of education;

(iii) as a result of (ii), an increasing division between the "have" and "have nots" as government schools often face shortages of qualified English teachers and lack access to suitable materials; 
(iv) limited support for indigenous languages in education, and often they are present in policy documents but not in reality;

(v) as a result of (ii) and (iv) many children are having to learn in languages they do not understand.

A notable exception to proving limited support to indigenous languages is the Outer Circle country, The Philippines, where 19 of the nation's 170 or so languages have been introduced as mediums of instruction for the first three years of primary school (Young \& Igcalinos 2019). However, the national language, Filipino, and English remain the major languages of secondary education, and English the primary language of higher education.

Indonesia is also unique in that it is the only one of the ten countries of ASEAN that does not make English a compulsory subject in primary school. Indonesia is the most linguistically diverse nation in Asia, being home to more than 700 languages. Given Indonesia's diversity, size, and recent decentralisation policies, it is hard to know how many of these languages are actually being taught in a systematic way. Kohler (2019) reports that some of the larger languages, such as Sundanese and Javanese, are taught in secondary schools. Local languages with fewer speakers, such as Buginese, are also taught in some areas where Buginese is the native language, but not in all such areas. Yet, despite its not being a compulsory subject in primary schools, English is also the second language of education in Indonesia, and there is evidence that it is being adapted by Indonesians to reflect their own cultural norms and values. For example, some pesantren (schools which are attached to mosques) are teaching English for Islamic purposes (Fahrudin 2013). As an example, when speaking about future plans, students are taught to end their English sentence or utterance with "Insya Allah" (Allah willing), thus conforming to Muslim practice in noting that all plans are subject to the will of Allah. Indonesians also understand the important role English can play in telling the world about Indonesian cultures and values. In a study in which she surveyed attitudes of a sub-section of Indonesians towards English, Dewi (2012) interviewed staff from a number of universities in Yogyakarta, including Islamic, Christian, and secular institutions. Generally speaking, the respondents reported that English was useful in allowing their voices to be heard, as these three typical responses indicate:

"I learn English because I want to be heard."

"English can boost our confidence as a nation."

"English makes me more confident I do not feel inferior anymore."

(Dewi 2012: 16-17).

None of the respondents saw English as a threat to their religion or way of life. Indeed, the Muslim respondents noted that

"[English] is also necessary for us to master English for proselytising,"

"English helps the development of my religion," and "

English can deliver information about my religion” (Dewi 2012: 22). 
Therefore, far from simply being a foreign language learned in schools, English has become adopted and adapted by speakers from the traditional Expanding Circle countries of Asia for their own needs. A recent edited volume Teacher Education for English as a Lingua Franca: Perspectives from Indonesia (Zein 2018) provides evidence as to how English is becoming a language of Asia. The authors of one chapter (Musthafa, Hamied \& Zein 2018) make a number of recommendations for re-imagining English in the Indonesian and Asian context. These include re-orienting the objectives of English language education in Indonesia. Such an adjustment would involve switching the focus of the classroom from Inner-Circle varieties of English to regional varieties and the use of English as a lingua franca. It would also involve developing students' intercultural literacy with regard to regional cultures (and, of course, that of their teachers). The authors also recommend that Pre-service teacher education prepare teachers with exposure to the varieties of English used in ASEAN in order to show that communication can be accomplished without adherence to native-speaking norms.

I shall return to the implications of how the roles of English have changed in the Expanding Circle countries of Asia in the third part of this article. Here I turn to describing how English, as noted by Musthafa et al. above, is becoming increasingly used as a lingua franca among Asian multilinguals across Asia.

\section{The role of English as a Lingua Franca}

I start this section of the article by quoting from Graddol's Afterword in his book English Next: India:

Throughout India, there is an extraordinary belief, amongst almost all castes and classes, in both rural and urban areas, in the transformative power of English. English is seen not just as a useful skill, but as a symbol of a better life, a pathway out of poverty and oppression.... How can the benefits of English be enjoyed without damaging the potential that India's multilingualism brings, as a source of unique identity in a globalised world, of cultural richness, and an important future economic resource? (Graddol 2010: 124)

I have referred to this tension between the apparent benefits of English and those of multilingualism when discussing the role of English in Nepal above, and I shall return to this issue in the third section of this article. Here I note that this "extraordinary belief ... in the transformative power of English" is shared across many of the countries of Asia. This is one reason why ASEAN has made English the sole working language of the group. Article 34 of the ASEAN Charter, which was signed in 2009, simply states, "The working language shall be English" (Kirkpatrick 2010). The importance attached to English was stressed in a speech in 2013 by the then Director General of ASEAN, Le Luong Minh:

With the diversity in ASEAN reflected in our diverse histories, races, cultures and belief systems, English is an important and indispensable tool to bring our 
Community closer together. [...] Used as the working language of ASEAN, English enables us to interact with other ASEAN colleagues in our formal meetings as well as day-today communications. [...] In order to prepare our students and professionals in response to all these ASEAN integration efforts, among other measures, it is imperative that we provide them with opportunities to improve their mastery of the English language, the language of our competitive global job market, the lingua franca of ASEAN (ASEAN 2013).

In addition, therefore, to the beliefs in the transformative power of English, by making English the sole working language of the group, ASEAN has provided a further important motivation for the peoples of ASEAN to learn English. The result, as illustrated in Table 2 above, is that English has become the second language of education of nine of the ten member nations of the group and the first language of education in Singapore. But the role of English as a lingua franca extends far beyond ASEAN. English has also become the working language of extended regional groups, including the so-called ASEAN + 3, comprising ASEAN and China, Japan, and Korea, and the Asia-Pacific Economic Cooperation forum (APEC), comprising 21 countries, the 13 of ASEAN + 3 along with Australia, Canada, Chile, Mexico, New Zealand, Papua New Guinea, Peru, Russia, and the United States. APEC issued a statement as long ago as 2003 urging member countries "to undertake measures to provide adequate knowledge and practical use of English as a working language within the APEC region" (Lazaro \& Medalla 2004: 278).

To illustrate how English is actually being used as a lingua franca in these ASEAN/Asian contexts, a number of examples are provided below. These excerpts are all taken from the Asian Corpus of English, a corpus of the naturally occurring use of English as an Asian lingua franca. ACE is freely accessible on line (https://corpus.eduhk.hk/ace). The first two examples discuss language and how the speakers view language and identity. In the first extract, a Bruneian of Chinese ethnicity (S2) is talking about her language journey as she describes the languages she grew up with and how she came to study English. The other participants are a Filipina (S1), a Thai male (S3) and a Vietnamese female (S4). SX indicates that it is not possible to determine who is speaking. SX-f means it is a female speaking, but that it is not possible to determine which one.

(1)

S2: my first language when i fam- when i'm at home in the family are actually dialect chinese dialects i speak a few languages well i speak to my father in a different dialect $i$ speak to my mother in a different dialect-kay so that is when $\mathrm{i}$ am at the age of one one to three one to four

SX-family

S3: chinese dialect

S1: growing

$\mathrm{S} 4: \mathrm{mhm}$ 
S2: so two dialects growing at the same time and at the same time our neighbours spoke malay

S4: $\mathrm{mhm}$

S3: $\mathrm{mhm}$

$\mathrm{S} 2$ : we live in an area where there were a lot of malays there were a lot of malays li- living in the area as well

$\mathrm{S} 1$ : your mother's chinese

$\mathrm{S} 2$ : my father's chinese my mother is chinese

$\mathrm{S} 4: \mathrm{mhm}$

S2: erm so but we spo- $i$ spoke dialect chinese: so i had so i grew up with a lot of languages around me

S1: that's interesting

S2: and i don't i don't actually remember

SX-f: (laughter)

$\mathrm{S} 2$ : how $\mathrm{i} i$ only knew that $\mathrm{i}$ was drilled in grammar but erm $\mathrm{i}$ felt for a ve- very long time that even when $i$ was $i$ can still think back and $i$ was in kindergarten i could understand the teacher

SX-f: okay

S1: uh-huh

S4: hm

S2: and she spoke erm english

SX-f: hm

S2: at that time so it wasn't a major difficulty because i was so small and so young

$\mathrm{S} 1$ : eah yeah so what would you say is er what is your first language now

S2: definitely english now i mean english has become $i$ think in english $i$

S3: English english

SX-f: (laughter)

S4: so you have so you have your mo- mother tongue father tongue

SX-(laughter)

S2: in the language i use most

$\mathrm{S} 1$ : neighbourhood tongue

(Kirkpatrick 2021: in press)

In this excerpt, S2 recounts that she grew up speaking different dialects of Chinese - the dialects spoken by her mother and father. At the same time, the language of her neighbours was Malay and then she learned English at school. In other words, she grew up multilingual speaking (at least) four languages. She concludes by saying that English is now her strongest language.

In the second example, a Malay female of Chinese ethnicity is talking to an Indonesian male about the daughter of a mutual friend who has recently left for England where she will train as an English teacher.

(2)

S2: and she's she is been: er: england before or not she's been in england before or not

S1: yes: been 
S2: yah been she has been in england before or not

S1: before yes she's stu er: she was study there

S2: uh-huh you sure

S1: yah:

S2: er i just last time we go to her room then i saw her daughter's picture daughter daughter's

S1: she graduated in england

$\mathrm{S} 2: \mathrm{hh}$

$\mathrm{S} 1$ : for the undergraduate

S2: o:h that's why she's:

$\mathrm{S} 1$ : yah for the degree program that's why

S2: yah she speaks

S1: she can speak

S2: a lot yah

$\mathrm{S} 1$ : english properly

$\mathrm{S} 2: \mathrm{mhm}$

S1: and then even she cannot speak malay (laughter)

S2: she cannot

$\mathrm{S} 1$ : she cannot er i mean she can but not fluently yah

S2: just a few oh

S1: she cannot speak engli- er:: malay fluently

S2: she's still here or she's already

S1: she's still here she she's: she teaches the: english course

(Kirkpatrick 2021: in press)

While both participants agree that their friend's daughter speaks excellent English (she can speak it "properly"), they also note that she is not fluent in her mother tongue, Malay. In both these examples of the use of English as a lingua franca, we can see that the learning of English means that other languages in the speaker's repertoire may be weakening, representing how the tension between English and multilingualism is reflected in the real lives of people. But, at the same time, they illustrate how widespread the use of English has become in these contexts

These two examples present relatively informal conversations between acquaintances. The next example is more formal. It is taken from a Chinese currentaffairs television programme. The host, Tian Wei (S1), is interviewing Najib Razak (S2), who was the Prime Minister of Malaysia at the time of the interview. The interview was conducted entirely in English and was destined for a Mainland Chinese audience, and thus provides further evidence for the increasing role of English in China.

(3)

S1: Mister Prime Minister welcome to our dialogue

S2: thank you

After a wide-ranging discussion, the interviewer raises the issue of ignoring difficult topics being part of Asian culture. Prime Minister Najib first agrees, but then adds that it is also a practical way of dealing with problems. 
(3 cont.)

S2: I agree with you I think er if there are some rather intractable problem or seemingly intractable problems then we should put those problems aside put those problems on the back burner for a while you know and and work on things that can lead to: results

$\mathrm{S} 1$ : is it in Asian culture?

S2: yeah it's part of Asian cul but it's it's a very pragmatic way of looking at things 'cos if you can't solve the problem er you know put it aside and and look at into other areas that you can really build on and build on that relationship and if the relationship gets stronger and stronger and stronger er you know the problem that you wanted to attend to earlier probably would not be so unbearable or so un- insurmountable when you look at it sometime in the future.

(Kirkpatrick 2021: in press)

The Asian Corpus of English contains many more examples of the way English is currently being used as a lingua franca among Asian multilinguals. I have included these three examples to give readers a flavour of the way English as a lingua franca is being used and to illustrate how English has become far more than simply a "foreign" language restricted to the language classroom in the Expanding Circle countries of Asia. Far from being simply a classroom-based foreign language, English has developed wide-ranging roles not only within Outer Circle countries but also within Expanding Circle countries. And it has become the major lingua franca of the region. In his 1998 article "English as an Asian Language" Kachru noted that English was usually described as being a language in Asia, but not of Asia. Kachru then lists five uses of English in Asia (1998: 102-3). They are:

(i) as a vehicle of linguistic communication across distinct linguistic and cultural groups;

(ii) as a nativised medium for articulating local identities within and across Asia;

(iii) as one of the Pan-Asian languages of creativity;

(iv) as a language that has developed its own subvarieties indicating penetration at various levels;

(v) as a language that continues to elicit a unique love-hate relationship that, nevertheless, has not seriously impeded its spread, function and prestige.

In discussing the current myriad uses of English within and between the Expanding Circle countries in a range of contexts from informal to formal and which include the five uses listed by Kachru above, we can conclude that English is now not only a language in Asia but of Asia. In the third section of the article I shall consider the implications of this for the teaching of English and language education policy in Asia's Expanding Circle.

\section{Implications for pedagogy and policy}

One of the recommendations that Musthafa, Hamied, and Zein (2018) made was for English to be re-oriented away from Inner Circle varieties of English to 
regional varieties and the use of English as a lingua franca. As English is being used as a lingua franca, it makes sense to teach it as one. I have recently developed a set of five principles for adopting a lingua franca approach to the teaching of English in this context (Kirkpatrick 2018, 2021) which I repeat here with a brief explanation for each of the five principles. The first two principles echo three of Kachru's famous six fallacies, namely that the goal of English learning is to interact with native speakers, to learn about British or American cultural values and to adopt native models of English (Kachru 1992: 357 ff).

Principle 1: The native speaker of English is not the linguistic target. Mutual intelligibility is the goal.

I have illustrated how English is operating in the Expanding Circles of Asia and noted that there are as many Expanding Circle users of English in Asia as there are native speakers of it worldwide. I have also shown how English is being used as a lingua franca not only between Asian multilinguals from the Expanding Circle countries but across Asia as a whole. It follows that Asian multilinguals are more likely to be using English with their fellow Asian multilinguals than with native speakers. The goal of English learning and teaching should, therefore, be to ensure successful communication among Asian multilinguals. Familiarity with the English used by Asian multilinguals becomes more important than familiarity with native speaker varieties of English. The ability to make oneself understood becomes more important than approximating native speaker models of English. The primary goal of learning and teaching English is to ensure one can understand and, in turn, be understood by fellow Asian multilinguals. Hence, the principle states that mutual intelligibility among Asian multilinguals is a more important goal than approximating a native speaker's variety of English.

Principle 2: The native speaker's culture is not the cultural target. Intercultural competence in relevant cultures is the goal.

Following on from the above, as Asian multilinguals are most likely to be using English with their fellow multilinguals, it is the cultures which are associated with these Asian multilinguals that become important for learners of English in which to become knowledgeable. For example, Indonesians speaking to Chinese need to know more about each other's cultures than they do about American, Australian or British cultures. Leaners need to become familiar with the cultures of the people they are most likely to be interacting in English with. Hence the principle prioritises developing inter cultural competence in relevant cultures as more important than developing knowledge about native speakers' cultures.

Principle 3: Local multilinguals who are suitably trained provide the most appropriate English language teachers.

As mutual intelligibility and intercultural competence in relevant cultures become the major goals of the learning and teaching of English in this context, 
English teachers who share or are familiar with their learners' linguistic and cultural backgrounds become appropriate teachers of English for Asian multilinguals. They need, of course to be well-trained as teachers of English and possess valid qualifications.

\section{Principle 4: Lingua franca environments provide excellent learning} environments for lingua franca speakers.

Learners of English whose main aim is to communicate with fellow Asian multilinguals would benefit more by studying in true lingua franca environments rather than travelling to countries of the Inner Circle in order to develop their English proficiency. True lingua franca environments are those where English is used naturally as a lingua franca. These include places such as the Philippines, Malaysia and Hong Kong. Indeed, the Philippines has become a popular place for many Asian students to develop their English. Besides the cheaper cost of studying in the Philippines, students are likely to feel more comfortable using English in such an environment, not least because of the absence of the native speaker. In a recent study of university students in Hong Kong, Sung (2017) reported that local English majors felt that they were confident users of English when conversing with fellow non-native speakers of English, but they felt they were learners of English when conversing with native speakers, and worried about making mistakes. Hence, Principle 4 recommends lingua franca environments as suitable places for Asian multilinguals to develop their English skills.

\section{Principle 5: Assessment must be relevant to the context.}

I shall not say too much about Principle 5 here (see Kirkpatrick 2018, 2021 for more detail, also see Newbold 2018, Tsagari \& Kouvdou 2018) except to stress that if we teach English as a lingua franca, we must assess it as lingua franca. Assessment must be valid and reliable.

These five principles frame a lingua franca approach to the teaching and learning of English in the Expanding Circle countries of Asia. Similar approaches for different contexts have been proposed by scholars such as Dewey (2012), Galloway and Rose (2018), Sifakis and Tsantila (2018), and Matsuda (2019).

I want to conclude this section by considering some of the implications of the increased role of English for language education policy. As was exemplified in Table 2 above, the great majority of countries of Asia have prioritised English as the second language of education. Ministries have also been introducing English earlier and earlier into the school curriculum in the belief that, with regard to language learning, "the earlier the better." Despite many scholars arguing against this position (e.g., Benson 2008, Kirkpatrick 2010, Coleman 2011) this belief remains resilient. This is unfortunate, as not only does the early introduction of English lead to children failing to learn English, the consequent lack of attention to indigenous languages and their neglect as languages of education also results in children having to learn content subjects in a language they do not understand, a 
trend reported in the study of language education policy across Asia (Kirkpatrick \& Liddicoat 2019). I have argued elsewhere (Kirkpatrick 2010) that English can quite reasonably be delayed until secondary school, allowing primary schools to focus on developing literacy in the national language and, where relevant and practical, the child's home language. Language education policy in the region needs to move from prioritising both the national language and English, and to provide for conditions favourable to the development of literacy in local languages and English (Sah 2020). Children could thus graduate from secondary school, confident in their home and the national language while also being functionally proficient in English. At present, too many children are failing to learn both English and content subjects in primary school, at great emotional and economic cost to themselves, their families, their communities, and their respective nations as a whole.

\section{Conclusion}

In this article I have illustrated how, far from simply being a foreign language learned in schools, English in the Expanding Circle countries of Asia is playing ever-increasing and diverse roles. I have exemplified uses of English both from the perspective from within countries and between them, and given some examples from the Asian Corpus of English (ACE) of how English is being used as a lingua franca by Asian multilinguals. These examples illustrate how Expanding Circle Englishes express the linguacultural identity of their users (Proshina 2019). I have put forward five principles for the adoption of a lingua franca approach to English teaching in light of these developments. At the same time, I have argued that this increasing role of English and its perceived importance in these contexts means that governments are, not unnaturally, prioritising English as the primary language of education and introducing it earlier and earlier into the curriculum. As a result, indigenous languages are being neglected as languages of education. I have therefore argued that language education policies should be revised in ways that would allow primary schools to focus on the national and relevant indigenous language(s), leaving the introduction of English to the secondary school. This would leave ample time for students to become functionally proficient in the language that is likely to play a greater and greater role in the Expanding Circle countries of Asia for the foreseeable future.

(C) Andy Kirkpatrick, 2020
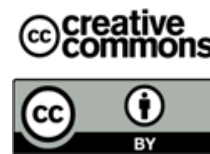

This work is licensed under a Creative Commons Attribution 4.0 International License https://creativecommons.org/licenses/by/4.0/ 


\section{REFERENCES}

ASEAN. 2013. Educating the next generation of workforce: ASEAN perspectives on innovation, integration and English. Keynote address presented at the British Council Conference, Bangkok.

Benson, Carol. 2008. Summary overview. Mother tongue-based education in multi-lingual contexts. In Caroline Haddad (eds.), Improving the Quality of Mother Tongue-based Literacy and Learning. Case Studies from Asia, Africa and South America, 2-11. Bangkok: UNESCO.

Bolton, Kingsley \& John Bacon-Shone. 2020. The statistics of English across Asia. In Kingsley Bolton, Werner Botha \& Andy Kirkpatrick (eds.), The Handbook of Asian Englishes, in press. Hoboken, N.J: Wiley-Blackwell.

Bolton, Kingsley, Werner Botha \& Wei Zhang. 2020. English in contemporary China. In Kingsley Bolton, Werner Botha \& Andy Kirkpatrick (eds.), The Handbook of Asian Englishes, in press. Hoboken, N.J: Wiley-Blackwell.

Coleman, Hywel. 2011. Developing countries and the English language. In Hywel Coleman (eds.), Dreams and Realities: Developing Countries and the English Language, 1-14. London: The British Council.

Dewey, Martin. 2012. Towards a post-normative approach: Learning the pedagogy of ELF. Journal of English as a Lingua Franca 1 (1). 141-170.

Dewi, Anita. 2012. Is English a form of imperialism? A study of academic community's perceptions at Yogyakarta universities in Indonesia. Asian Englishes 15 (1). 4-27.

Fahrudin, Didi. 2013. English language teaching material development in pesantren institutions: A transcultural flow experience in Indonesia. In $5^{\text {th }}$ COTEFL Conference, Purwokerto, Indonesia. 11-12.

Feng, Anwei \& Robert B. Adamson. 2019. Language policies in education in the People's Republic of China. In Andy Kirkpatrick \& Anthony J. Liddicoat (eds.), The Routledge International Handbook of Language Education Policy in Asia, 45-59. London and New York: Routledge.

Galloway, Nicola \& Heath Rose. 2018. Incorporating Global Englishes into the ELT Classroom. ELT Journal 72 (1). 3-14.

Galloway, Nicola, Takuya Numajiri \& Nerys Rees. 2020. The "internationalisation" or "Englishisation" of higher education in East Asia. Higher Education. doi: 10.1007/s10734-019-00486-1.

Graddol, David. 2010. English Next: India. London: The British Council.

Kachru, Braj B. (ed.). 1992. The Other Tongue: English across Cultures. $2^{\text {nd }}$ edn. Urbana: University of Illinois Press.

Kachru, Braj B. 1998. English as an Asian language. Links \& Letters 5. 89-108.

Kirkpatrick, Andy. 1995. Chinese rhetoric: Methods of argument. Multilingua 14 (3). 271-295.

Kirkpatrick, Andy. 2010. English as a Lingua Franca in ASEAN: A Multilingual Model. Hong Kong: Hong Kong University Press.

Kirkpatrick, Andy. 2011. English as a medium of instruction in Asian education (from primary to tertiary): Implications for local languages and local scholarship. Applied Linguistics Review 2 (1). 99-120.

Kirkpatrick, Andy. 2015. Chinese English or English Chinese? Global Chinese 1 (1). 85-110.

Kirkpatrick, Andy. 2018. Concluding chapter. In Nicos Sifakis \& Natasha Tsantila (eds.), ELF for EFL Contexts, 229-241. Clevedon: Multilingual Matters.

Kirkpatrick, Andy. 2021. Is English an Asian Language? Cambridge: Cambridge University Press. 
Kirkpatrick, Andy \& Anthony J. Liddicoat. 2017. Language education policy and practice in East and Southeast Asia. Language Teaching 50 (2). 155-188.

Kirkpatrick, Andy \& Anthony J. Liddicoat (eds.). 2019. The Routledge International Handbook of Language Education Policy in Asia. London and New York: Routledge.

Kirkpatrick, Andy \& Xu Zhichang. 2001. The new language law of the People's Republic of China. Australian Language Matters 9 (2). 14-18.

Kohler, Michelle. 2019. Language education policy in Indonesia - a struggle for unity in diversity. In Andy Kirkpatrick \& Anthony J. Liddicoat (eds.), The Routledge International Handbook of Language Education Policy in Asia, 286-297. London and New York: Routledge.

Lazaro, Dorothea C. \& Erlinda M. Medalla. 2004. English as the language of trade, technology and finance in APEC: An East Asia perspective. Philippine Journal of Development 31 (2). 278-300.

Lewis, Paul, Gary Simons \& Charles Fennig. 2015. Ethnologue: Languages of Asia. SIL International.

Li, Wei. 2014. New Chinglish: Translanguaging, creativity and criticality. Plenary presentation at the AILA Conference, Brisbane, August 11-15.

Matsuda, Aya. 2019. World Englishes in English language teaching: Kachru's six fallacies and the TEIL paradigm. World Englishes 38 (1-2). 144-154.

Musthafa, Bachrudin, Fuad Abdul Hamied \& Subhan Zein. 2018. Enhancing the quality of Indonesian teachers in the ELF era: policy recommendations. In Subhan Zein (eds.), Teacher Education for English as a Lingua Franca, 175-190. London \& New York: Routledge.

Newbold, David. 2018. ELF in language tests. In Nikos Sifakis \& Natasha Tsantila (eds.), English as a Lingua Franca for EFL Contexts, 195-209. Bristol: Multilingual Matters.

Phyak, Prem \& Laxmi Prasad Ojha. 2019. Language education policy and inequalities of multilingualism in Nepal: Ideologies, histories and updates. In Andy Kirkpatrick \& Anthony J. Liddicoat (eds.), The Routledge International Handbook of Language Education Policy in Asia, 341-354. London \& New York: Routledge.

Proshina, Zoya. 2019. Elaborating on the Expanding Circle. World Englishes 38 (1-2). 233-244.

Sah, Pramod. 2020. English medium of instruction in South Asia's multilingual schools: unpacking the dynamics of ideological orientations, policies/practices and democratic questions. International Journal of Bilingualism and Bilingual Education. doi:10.1080/13670050.2020.1718591.

Sifakis, Nicos \& Natasha Tsantila (eds.). 2018. English as a Lingua Franca for EFL Contexts. Bristol: Multilingual Matters.

Sung, Matthew. 2017. Exploring language identities in English as a lingua franca communication: Experiences of bilingual university students in Hong Kong. International Journal of Bilingualism and Bilingual Education 23 (2). 184-197.

Sunuwar, Dev Kumar. 2020. Minority languages are endangered but nobody cares in Nepal. Ogmios 66. 11-14.

Tsagari, Dina \& Androniki Kouvdou. 2018. Towards an ELF-aware alternative assessment paradigm in EFL contexts. In Nikos Sifakis \& Natasha Tsantila (eds.), English as a Lingua Franca for EFL Contexts, 210-228. Bristol: Multilingual Matters.

$\mathrm{Xu}$ Zhichang. 2010. Chinese English: A future power? In Andy Kirkpatrick (ed.), The Handbook of World Englishes, 282-289. London: Routledge.

Young, Catherine \& Tony Igcalinos. 2019. Language-in-education policy development in the Philippines. In Andy. Kirkpatrick \& Anthony J. Liddicoat (eds.), The Routledge 
International Handbook of Language Education Policy in Asia, 165-184. London and New York: Routledge.

Zein, Subhan (ed.). 2018. Teacher Education for English as a Lingua Franca. London \& New York: Routledge.

Zhang, Wei. 2012. Chinese-English code-mixing among China's netizens. English Today 28 (3). 40-52.

Article history:

Received: 19 March 2020

Revised: 13 July 2020

Accepted: 15 July 2020

\section{История статьи:}

Дата поступления в редакцию: 19 марта 2020

Дата принятия к печати: 15 июля 2020

\section{Bionote:}

Andy KIRKPATRICK is Professor in the Department of Humanities, Languages and Social Science, at Griffith University, Australia and is a Fellow of the Australian Academy of the Humanities. His most recent books include The Routledge International Handbook of Language Education Policy in Asia (co-editor with Anthony J. Liddicoat), The WileyBlackwell Handbook of Asian Varieties of English (2020, co-editor with Kingsley Bolton and Werner Botha) and Trilingual Education in Hong Kong Primary Schools (2019, coauthor with Wang Lixun). The second edition of the Routledge Handbook of World English, of which he is the sole editor, will be published in late 2020. His monograph $I S$ English an Asian Language? will be published by Cambridge University Press in 2021.

\section{Contact information:}

Griffith University, Humanities, Languages and Social Science

170 Kessels Road, Nathan, Queensland 4111, Australia

e-mail: a.kirkpatrick@griffith.edu.au

ORCID ID: 0000000244707089

Scopus ID: 22934945300

\section{Сведения об авторе:}

Энди КИРКПАТРИК - профессор факультета гуманитарных наук, языков и социальных наук в Университете Гриффита, Австралия. Член Австралийской академии гуманитарных наук. Его опубликованные за последнее время книги включают The Routledge International Handbook of Language Education Policy in Asia (соредактор с Энтони Дж. Лиддикоутом), The Wiley-Blackwell Handbook of Asian Varieties of English (2020, совместно с Кингсли Болтоном. и Вернером Бота) и Trilingual Education in Hong Kong Primary Schools (2019, соредактор с Ван Лисюнем). Его монография Is English an Asian Language? будет опубликована Издательством Кембриджского университета в 2021 г.

\section{Контактная информация:}

Griffith University, Humanities, Languages and Social Science

170 Kessels Road, Nathan, Queensland 4111, Australia

e-mail: a.kirkpatrick@griffith.edu.au

ORCID ID: 0000000244707089

Scopus ID: 22934945300 